\title{
SEMANTIC ANALYSIS IN ENGLISH HIGH SCHOOL HANDBOOKS
}

\author{
Salmia Syarifuddin ${ }^{1}$ \\ Irmawaty Hasyim ${ }^{2}$ \\ Department of English Education, Faculty of Letters \\ Universitas Muslim Indonesia \\ salmia.syarifuddin@umi.ac.id
}

\begin{abstract}
This paper aims to discover semantical meaning found in the literary work in the English handbook of high school using a semantic approach. This study applied a descriptive qualitative method. The data in this study were phrases, sentences, and clauses that allegedly contain implicit and explicit meanings. The literary work analyzed was taken from three (3) handbooks for high school student. The results of the study showed various types of semantic meanings in literary works found in the English handbook as teaching materials. The types of semantics meaning found in the English Handbook for high school were literal and non-literal meaning. These meanings did not appear together in one literary work, but it is spread in the literary works found in the English handbooks.
\end{abstract}

Keywords: semantics, meaning, handbook, literary work

\section{INTRODUCTION}

Language as a means of communication for human beings also has a crucial role in learning media. In the educational world, learning media is a tool or a medium between teachers and students to communicate and to transfer the knowledge. One of the learning media mostly found in as material in teaching is literary work. This literary work can be found in students' handbook in the form of a short story, lyric, poem, song, novel review and many more.

It is known that literary works are the works of art produced by the writers' imagination that occurred around them or even the results of their personal experience which is then poured in the form of writing that is full of beautiful and poetic language. In addition to common reading materials, literary works are also widely used as one of the objects chosen as a media in learning the English language. This is because literary works are writings reflecting the social life of society and human culture that directly or indirectly can provide a variety of experiences that can be learned. Besides, it contains moral values or character education for its readers.

\section{British, Jurnal Bahasa dan Sastra Inggris}


Literature cannot be separated from linguistics. It is because literature using language science or linguistics to convey the content and moral message and its beauty to the reader. Literary works are also widely used as learning media in education both high school level and college. Therefore, prospective teachers should know how to analyze literary works from both intrinsic and extrinsic elements. Sometimes, it is felt confusing when a student or even a teacher who are not mingling with literature. As a result, people as a common reader mix it between language and literature. These two things are very different from one another. It should be emphasized that language is a means of communication that is used in literature to convey its content and beauty while literary work is work that is talked on. Then, it is to confirm that language is a means in communication used in the literary work for the reader to understand the moral lesson or the hidden meaningful meaning inside the work. Thus, this study was conducted to answer these questions, uncover and explore ways to analyze the semantic meanings found in the learning media on English materials for high school students.

Discussing meaning, there are some researchers have done their research in analyzing meaning. According to Djajasudarma (2012), the meaning is the association that exists between the elements of the language itself (especially the words), while according to Palmer (1982), the meaning is only concerned with the element in the language itself. Thus, the meaning is an important aspect in a language because the meaning can give an understanding of the matters talked on that spot. As a result, the communication can happen smoothly and understand one another are built in automatically. Nevertheless, if the users of the language in speaking one another do not understand the meaning of the word, then it is unlikely that the speech or topic that is talked on can result in a bias communication. Therefore, speakers and hearers must understand each other's language meaning. Besides, Aminuddin (2015) says that language sounds implicitly contain certain meanings.

Lyons (1995) suggests that semantics is a study of the meaning of sentences. So, the understanding of semantics gives an understanding of the study of 
meaning in sentences. It is a piece of common knowledge to know that a sentence built from classes of speech, either is noun, verb, or adjective. It is also clarified by Ng'ang'a (2003) that the classification of nouns and verbs into clusters of semantically similar words is done based on this contextual encoding. It is then confirmed that the built-in of a sentence results from an encoding of a language in which it also built in a meaning inside the structured sentence. Furthermore, Tarigan (2009) suggested that semantics are meaning. It strengthened the opinion on the context built the meaning of a structure sentence as mentioned before. Besides, it emphasized that to study emblems or signs that express meaning, the relationship of meaning to one another, and its influence on people and society.

Geoffrey Leech in his book 'Semantic- A Study of Meaning' (1985) breaks down meaning into seven types or ingredients giving primacy to conceptual meaning. The seven (7) types of meaning divided by Leech are, as follows:

1. Conceptual Meaning (It is logical, cognitive or denotative content. It is also known as primary meaning in which its meaning appears in the dictionary to show the real meaning of an object).

2. Connotative Meaning (It is communicated by virtue of what language refers. It is also meaning for an expression shown to an object communicated in a certain conceptual situation).

3. Social Meaning (It is communicated of the social circumstances of language. It also related to the value built in a society and custom of a certain community).

4. Affective Meaning (It is communicated of the feelings and attitudes of the speaker through language. This meaning also appears based on the situation or conceptual situation faced by the speaker).

5. Reflected Meaning (It is communicated through associations with another sense of the same world. It also builds a multi conceptual meaning of a word meaning in one condition and it depend on its speaker's knowledge of the word). 
6. Collocative Meaning (It is communicated through associations with words which co-occur with another word. It associates one word with another word to build a new word with a certain meaning).

7. Thematic Meaning (It is communicated by the way in which the message is organized in terms of order and emphasis. It makes the speaker organizing the hearer to focus on a certain theme).

On the other hand, lexical semantics are semantic studies that focus more on the discussion of the meaning system found in the word. The lexical semantics observe the meanings contained in the word as independent units (Pateda, 1996). This opinion is in line with the research result done by Ivanovska, Biljana, Nina and Mahmut (2012) who found that the approach for analysis varies from language to language and depends on the different language systems of the languages being compared. It demands careful preparation and it can be used to explain the difference in the meaning of the lexical units. In the performed analysis, concepts such as "semantic" and "lexical field" are of significant importance. It makes it clear that, by analyzing the structured sentences within its context, a lexical-semantic analysis is done through it. Thus, lexical meaning is considered as one of literal meaning in semantics.

In addition to the context of the sentences found in a literary work, factors like need, semantic similarity, and factors of social and psychological considerations (e.g. prestige, taboo) seem to be the potent factors at interplay in semantic change (Al-Athwary, 2016). It most likely happens during the life period and imagination of the author which is laid down on the story. Therefore, semantics include the meaning of the word, its development, and its changes depending on the content and context of the object, in this case, literary works as an object or medium of learning in English language teaching materials.

The literary work is one form of idiosyncratic which is the word spread used is the result of the processing and the individual expression of its author (Lyons, 1995). Facing the reality of the complexity of meaning in literary works, readers who want to understand literary works in earnest and truth certainly also have to understand the science of meaning (semantics). The semantics role is very 
important in literary studies, especially in the study of meaning (Aminuddin, 2015). Thus, the layer of meaning can occur in literary works where the literal meaning unit has explicitly represented the form of linguistic use, the author created the world that is viewed from a certain point of view.

Identifying literature in a handbook means doing grouping according to a particular viewpoint. While analyzing literature contains the intention that all efforts that are made to capture the meaning of a particular literary work. It is done very careful, thorough, and in-depth exposure to all elements or components so that we find a thorough meaning in an analysis of literary work (Teeuw, 1988).

Another research was done by Yulianingrum (2013), who found that the poem "Tintrim" by Lelana Brata in the anthology Gegurit Sewindu Pustaka Candra is worthy to be taught to vocational school's students because in the poem there is a lot of the development of soul maturity so that it can be used as an example for students, as motivation for students to learn. It seems to be crucial to consider language units from different perspectives - lexical, semantic and cognitive and take a view at different kinds and types of meanings to show how they fit into the total composite effect of a book jacket lexicon (Smoliana, 2013).

There are two kinds of meaning these are literal meaning and non-literal meaning. Literal meaning is the real meaning of words. Meanwhile non-literal meaning is unreal meaning of words; it is called figurative language which includes metaphor, irony, hyperbole, etc. Meanwhile literal meaning includes denotative, grammatical, lexical, connotative, contextual etc. Types of meaning discussed in this study were literal and non-literal meaning found in the English high school handbooks.

\section{RESEARCH METHOD}

This study used descriptive qualitative method. This method makes descriptions or depictions to understand the phenomenon of what is experienced by the research subjects such as behavior, perception, motivation, action, and others (Moleong, 2013). This method of research was chosen because the research data was descriptively based on the fact that it obtained in the form of writing,

\section{British, Jurnal Bahasa dan Sastra Inggris}


which was then analyzed and then interpreted in an objective and finally described in the form of beautiful words and language as a hallmark of literary work. The data obtained (in the form of words, phrases, clauses, and sentences) were not poured in the form of numbers or statistical numbers but rather remained in a qualitative form. It means more than just a number or frequency. The data were analyzed by describing the situation examined in the form of a narrative description (Margono, 2010).

\section{RESEARCH FINDING AND DISCUSSION}

The result of this study is the types of meaning and analysis that are widely used in English teaching materials. To be underlined here is that the types of meanings did not appear as a whole, both in the song, fable, short stories and poem analyzed in this study. Here are the semantics types of meaning found in the literary works within the English teaching material used by High Schools students.

\section{Bahasa dan Sastra Inggris untuk Siswa SMA/MA Kelas XI.2 Yrama Widya Publication}

\section{- Sleeping Child by Michael Learns to Rock}

$\square$ Metaphor (figurative meaning)

But you've built your own paradise

The line of the lyric of the song is the metaphor found in the song ' $O h M y$ Sleeping Child'. This represents something with a direct comparison based on the same or almost identical traits. In this case, paradise is considered a world built by children where only those owned it who are in it.

This metaphor used is directly expressed as an analgesic comparison. The innocence of children with a genuine heart is capable of moving an adult's heart to keep world peace from destruction. As long as children remain, people will continue to strive for a more peaceful and good world. They live, hope, fortress, and our last weapon in combating unwanted bad things. When adults are united to protect their children from the dangers of the world, it is the children who are protecting them. Those children give reasons for adults to stay in the struggle, passion, survival and strive for a better world for everyone.

\section{British, Jurnal Bahasa dan Sastra Inggris}


$\square$ Hyperbola

The world's so wild

In this line, the author exaggerates that the world has been so wild, and turbulent. Children who remain innocent even as the world gets longer nearer the destruction of adults due to war and conflict among others.

\section{Personification}

And Mr. World He came by, To greet goodnight to You

In the above line of the world borrow roles, a human duty to convey greetings to the child who will sleep.

\section{- Fable: The Boy who cried "Wolf"}

\section{Lexical meaning}

\section{Being alone}

The clause above means alone and lonely. It is said to have a lexical meaning because the change from word to the sentence does not alter the meaning of its literal meaning.

\section{Connotative Meaning}

\section{Shouted the boy at the top of his voice}

The meaning of the sentence above is the shepherd's child screaming until his voice is lost. This meaning includes connotation because it poses a less good effect on the listener. Also, the top of the voice phrase gives a blurred meaning because it is unlikely that the sound has a tip or a peak. Thus, this is where the implicit (implied) meaning gives the meaning that the shepherd is out of his voice, screaming.

\section{Nobody and bothered him this time}

The sentence above means no one has to mention the call, the cry of the shepherd's Child. In other words, he is no longer heard, because he likes to lie, so when he needs help, then nobody comes to him.

$\checkmark$ Grammatical meanings

A shepherd boy means a shepherd child who follows grammatical writing rules in the sentence structure in English. The phrase above is a noun phrase.

\section{British, Jurnal Bahasa dan Sastra Inggris}




\section{English Alive: Senior High School, Grade XII. 3 Penerbit: Yudhistira}

\section{- Story-Review: August Rush, Reviewed by Jeffrey Chen}

Connotative meaning

\section{Houses-often}

The word houses in the expression means home and often means frequent, but when these two words are merged it means a quaint house.

$\square$ Lexical meaning

Full length

Full means full length, length means long, but when both words are combined it means length.

\section{Contextual Meaning}

Tree feet high

Three feet high in the expression means three, feet means feet, and high means high, but if combined means something high.

\section{- Story-Review: Ryan Lochter on Course for Second Gold}

$\square$ Contextual Meaning

Split-true-lovers: The true love that parted

Left-learners-even: even leaving the lesson

China's Sun: the Chinese Pride

After a week of sunshine: a week after summer

Phrases in the form of the above phrases are said to have contextual meaning because when these expressions are used in different cases or situations, the meaning will also be different. For example, after a week of sunshine, this clause in the context of the story in the study means a week after summer, but when it appears in a different situation, the meaning will be different. After a week of sunshine can mean the sun shines, hope also arises.

Connotative meaning

Out-of-wedlock boy: illegitimate boy

The phrase above shows a very obvious connotative meaning, or can even be said literally. 
Lexical meaning

Slippery: Wet condition, lost time after rain until dry and can operate again.

Prelim: Preparatory Exam

Freestyle: one of the swimming styles used in swimming sports.

Blight: Hawar, one of the symptoms of an attack of a pathogen plant is characterized by changes in plant physique that begin with the screen of plant leaves.

Diuretic Furosemide: A potent diuretic (water pill) used to remove water and salt from the body.

\section{- Fable: The Lion and the Dolphin}

\section{$\square$ Personification}

The ruler of the sea

The word ruler means king or decision-maker and sea means a wide-open place, without corner. But if these words are combined into one then, it means the owner of the sea.

Denotative meaning

In a friendship relationship, we must always be positive-minded with each other and a friend must know the limitations of his friend. Besides, we must also ask people who we feel can help us. Just like a prelingual is not dependent on weak roots.

3. English for Senior High School Students XI Science and Social Study Programme: Jakarta. Grasindo

- Short story: The Queen of the Adriatic

Metaphor

City of Water

City of Bridges

The City of the Light

Denotative meaning

Shallow-Lagoon 
Shallow has a meaning that the lake is not deep. Lagoon means that a lake that is once part of a sea or small lake that occurs on a shallow sea surrounded by corals covering the coast or river.

Venetians-Travel

Venetia is the capital city of northern Italy. It is also referred to as the Queen of the Sea because it is surrounded by water and also called the City of Bridges and the City of Light.

\section{Contextual Meaning}

In a friendship relationship, we must always be positive-minded with each other and a friend must know the limitations of his friend. Besides, we must also ask people who we feel can help us. Just like a prelingual is not dependent on weak roots.

\section{- Short stories: Jaguar}

Lexical meaning

Distance to their residence from protected forest

The clause means that there is space, either it is wide or narrow that separates a residence. The residence is near a protected forest.

Grammatical meaning

\section{Later led to a dispute}

The clause showed an adverb to appear as the pre-determiner of the verb phrase. The meaning of this clause gives a literal meaning to the next sentence in the story.

\section{Ordinary leopard kills prey}

This simple sentence shows a noun phrase to be the subject of the sentence. It gives clear meaning to the reader.

$\square$ Contextual Meaning

\section{A leopard loves to roar}

This simple sentence also shows a noun phrase to be the subject of the sentence. It gives clear meaning to the reader. This sentence is considered to have contextual meaning due to the situation of the leopard to roar. It does not happen every time, but it should have a situation for a leopard to roar. 


\section{CONCLUSION AND SUGGESTION}

This study resulted in significant findings of discovering the type of meaning and its analysis using learning media, such as; short stories, songs/lyrics, fable, and story-review as the literary works found in the teaching materials. The conclusion that can be taken based on findings and discussions are, as follows:

(1) The most common types of meaning found in this study is the lexical meaning for literal meaning and metaphor for non-literal meaning.

(2) Literary works found in the English high school handbooks were short stories, fable, songs/lyrics, and stories or novel reviews. These kinds of literary works are most commonly found in English handbooks for high school.

\section{REFERENCES}

Al-Athwary, A.A.H. 2016. The Semantics of English Borrowings in Arabic Media Language: The Case of Arab Gulf States Newspapers. International Journal of Applied Linguistics and English Literature. Vol. 5, No. 4, pp: 110-121. DOI 10.7575/aiac.ijalel.v.5n.4p.110.

Aminuddin. 2015. Semantik: Pengantar Studi tentang Makna. Bandung: Sinar Baru. Algesindo.

Djajasudarma, T. Fatimah 2012. Semantik 1. Pengantar ke Arah Ilmu Makna. Cetakan ke 5. Bandung: Eresco.

Ivanovska, Bijlana, Daskalovska, Nina \& Celik, Mahmut. 2012. A Contrastive Analysis in the Meaning of the Linguistic Units in the Contemporary German and Macedonian Language. Procedia-Social and Behavioral $\begin{array}{lll}\text { Sciences. } & \text { Vol. } & \text { 46: }\end{array}$ https://doi.org/10.1016/j.sbspro.2012.05.274

Leech, G.N. 1985. Semantics: The Study of Meaning Second Edition-Revised and Updated. England: Penguin Books.

Lyons, J. 1995. Pengantar Teori Linguistik. Diterjemahkan oleh I Soetikno. Jakarta: Gramedia Pustaka Utama.

Margono, S. 2010. Metedologi Penelitian Pendidikan. Jakarta: Rineka Cipta.

\section{British, Jurnal Bahasa dan Sastra Inggris}


Moleong, Lexy J. 2013. Metodologi Penelitian Kualitatif. Bandung: PT. Remaja Rosdakarya.

Ng'ang'a, W. 2003. Semantic Analysis of Kiswahili Words Using the Self Organizing Map. Nordic Journal of African Studies, Vol. 12, No. 3 pp: 405-423 http://www.njas.helsinki.fi/pdf-files/vol12num3/nganga.pdf

Palmer. F.R. 1982. Semantics. Cambridge: Cambridge University Press.

Pateda, Mansoer. 1996. Semantik Leksikal. Ende-Flores: Nusa Indah.

Smoliana, A. 2013. Semantic Comprehension of Lexical Content of the English Book Jackets. European Scientific Journal. Vol. 9 No. 29, pp: 43-54.

Tarigan, Henry Guntur. 2009. Pengajaran Semantik . Indonesia :Angkasa Bandung.

Teeuw, A., 1988. Sastra dan Ilmu Sastra: Pengantar Teori Sastra. Jakarta: PT Dunia Pustaka Jaya.

Yulianingrum, Ayu. 2013. Analisis Semantik Puisi ‘Tintrim' Karya Lelana Brata dalam Antologi Gegurit Sewindu Pustaka Candra dan Skenario Pembelajarannya di SMK. Jurnal Program Studi Pendidikan Bahasa dan Sastra Jawa Universitas Muhammadiyah Purworejo Vol. 02(02): 31-36. Purworejo: UMP. 